\title{
Possible implementation of subjects taught using English as a Medium of Instruction methodology in tourism studies
}

\author{
Francisco J. Álvarez-Gil \\ francisco.alvarez@ulpgc.es \\ Universidad de Las Palmas de Gran Canaria, Spain
}

\begin{abstract}
Álvarez-Gil, F. J. (2021). Possible implementation of subjects taught using English as a Medium of Instruction methodology in tourism studies. Language Value, 14(2), 68-86. Universitat Jaume I ePress: Castelló, Spain. http://www.languagevalue.uji.es.
\end{abstract}

December 2021

DOI: $10.6035 /$ languagev.6129

ISSN 1989-7103

\section{ABSTRACT}

The present study analyses which conditions would be necessary to implement subjects taught using English as a Medium of Instruction (EMI) methodology in the undergraduate degree in tourism studies at the University of Las Palmas de Gran Canaria (ULPGC). In the literature review, some of the concepts related to this method are examined to clarify diverse methodological approaches that are frequently confused, namely Content and Language Integrated Learning (CLIL), EMI, and English for Specific Purposes. With the objective of finding out the specific conditions necessary for implementing EMI subjects in the Degree in Tourism at the ULPGC, a revision of EMI subjects that have been already implemented at this institution would be made. Then a proposal indicating the conditions that are regarded as vital for implementing EMI subjects in this degree would be presented.

Keywords: English as a Medium of Instruction (EMI); tourism; English for Specific Purposes (ESP); Universidad de Las Palmas de Gran Canaria; language teaching. 


\section{INTRODUCTION}

In the increasingly globalised world in which we live, there is a clear need to be able to communicate, make ourselves understood and transmit knowledge, and the academic sphere is no exception. The vast majority of higher education institutions in Spain are carrying out intense internationalisation work through collaboration agreements with foreign institutions and student exchange programmes, such as Erasmus, Erasmus Mundus and Fulbright scholarships. To participate in these exchanges, many higher education institutions require students to have a B1 level (CEFR) of the language spoken in the host country, which is normally the language used for the teaching sessions that the student will receive in that country during the exchange period. However, some studies have shown that this level of language proficiency is insufficient to follow the teaching sessions of subjects with very specific content, such as those taught at both undergraduate and postgraduate level.

Within the framework of this process of internationalisation, English is used as a lingua franca and has become increasingly important in university studies for the teaching of subjects within the curricula of official undergraduate programmes, for the teaching of short courses and for master's degrees, doctoral courses, etc. Moreover, higher education institutions have seen in the delivery of content in English an opportunity to attract international students, whose presence on campus provides multicultural enrichment and is also a factor that has a positive impact on their position in some international rankings measuring the quality of higher education institutions. As pointed out by Mendoza Domínguez (2017), there are several reasons why some universities add English-medium courses to the curricula of the degrees they offer:

The reasons why universities are willing to face EMI are numerous and complex: to attract international students, to be better positioned in the university rankings, to increase revenue, to give our students the possibility to study abroad, to further student and staff career possibilities, to modernize universities or even to follow global trends of how universities are supposed to become more international ("everybody is doing EMI now, so we should too").

As a result of globalisation, the importance of foreign languages, especially English as a lingua franca, has increased exponentially over the last few decades. This relevance of the English language has led to an immense proliferation of bilingual schools and to governments implementing bilingual education programmes at practically all educational levels. In the case of higher education, various subjects under the umbrella of English for Specific Purposes (ESP) have been introduced in the different syllabuses, especially at undergraduate levels. 
Similarly, other methodologies, such as English as a Medium of Instruction (EMI), have been implemented but are not so widespread; as seen in section two of this paper, its implementation in some institutions is not yet at the same level of popularity as ESP subjects. The number of studies on EMI is steadily increasing and scholars are still exploring diverse dimensions of this methodological approach. Some relevant studies on this topic published over the last decade include Smit and Dafouz (2012), Doiz et al. (2013), Dafouz and Camacho-Miñano (2016), Breeze and Dafouz (2017), Macaro (2018), Dafouz and Smit (2020), Carrió-Pastor (2020), FortanetGómez (2020) and Carrió-Pastor and Bellés-Fortuño (2021).

The recognition that this methodology has acquired and its implementation in education systems around the world has resulted in a proliferation of studies analysing multiple aspects of this methodological approach in each country, for example, the study by Macaro et al. (2019) on The Importance of Certification of English Medium Instruction Teachers in Higher Education in Spain, Tsou and Kao's (2017) analysis of the implementation and classroom practices of EMI in Taiwan and Tejada-Sanchez and Molina-Naar's (2020) analysis of the relationship between EMI and the internationalisation of higher education in Latin America using the case of a Colombian university as an example. Wilkinson (2012) conducted a review of the challenges and pitfalls of teaching EMI at a Dutch university while Furtado-Guimarães and Martins Kremer (2020) carried out a comparative study on the adoption of EMI in Brazil and Belgium.

The main objective of this study is to determine what the necessary conditions would be for the implementation of subjects taught using EMI methodology in the undergraduate degree in tourism studies at the University of Las Palmas de Gran Canaria (ULPGC). To achieve this objective, some of the concepts related to this methodological approach will be provided in the literature review in the next section so as to clarify three methodologies that are often confused - Content and Language Integrated Learning (CLIL), EMI and ESP. The current level of implementation of these methodologies in the ULPGC is also shown. The subsequent section provides a detailed analysis of the conditions necessary for implementing EMI subjects in the Degree in Tourism at the ULPGC, through the examination of the subjects already implemented in other degrees at this university. Following this, a proposal for the implementation of this methodology in the aforementioned degree is put forward, and the final section presents the conclusions of the study. 


\section{LITERATURE REVIEW, THE CLARIFICATION OF TERMINOLOGY AND THE CASE OF THE ULPGC}

The main aim of this section is to clarify a series of methodological concepts that often lead to confusion, not only among students and society in general but also among teachers and lecturers. In Spain, the confusion lies in the fact that there has been a lot of talk regarding CLIL but very little talk regarding EMI; therefore, many people are still unfamiliar with the term and there is a tendency to think that these two methodologies are the same or that the boundary between the two is blurred. This section also provides a concise literature review of the ESP methodology. To sum up, this section defines the concepts and discusses the scope of and main differences between ESP, CLIL and EMI.

In the ULPGC, the current range of subjects on offer includes some that fall within the categories of ESP and EMI. Although CLIL methodology is not employed within the subjects currently taught, this methodology is included within the description of the current literature on the topic in this work due to the frequent confusion regarding the distinction between EMI and CLIL; therefore, it is relevant to highlight what each of these methodologies consists of and the main differences between them.

\section{II.1. Definition of ESP and its current presence at ULPGC}

Relatively often, although to a lesser extent than with CLIL, there is a tendency to confuse the EMI methodological approach with that of ESP. As Dearden (2014, p. 4) notes, EMI is confused "with ESP...in which courses involve English for journalism or business studies for example, specifically designed to enable a student to undertake that profession in an English-speaking context". Currently, within the syllabus of the undergraduate degree in tourism, three subjects are taught in English, namely English for tourism I, II and III. They fall into the category of ESP, as they offer:

English language instruction that aims to serve learners' communication needs in English in a certain domain. In fact, addressing learners' specific goals to use English in a specific area is what distinguishes ESP from English for General Purposes teaching (Hyland, 2002). While in the 1960s, it emerged as a response to communication needs in English mainly in commerce, science, and technology (Swales, 1988), today, ESP encompasses a wide range of areas including English Academic Purposes (EAP), English for Medical Purposes (EMP), English for Business Purposes (EBP), English for Legal Purposes (ELP), and English for Sociocultural Purposes (ESCP) (Belcher, 2009) (Isik-Tas and Kenny, 2020, p. 1). 
The ULPGC provides ESP subjects in numerous undergraduate degrees, not only in tourism studies, as can be seen in Table 1, which shows the high number of ESP subjects currently taught at the ULPGC at undergraduate level, especially in the field of engineering and architecture.

Table 1. ESP subjects taught in undergraduate degrees at the ULPGC.

\begin{tabular}{|c|c|c|}
\hline $\begin{array}{l}\text { FIELD OF } \\
\text { KNOWLEDGE }\end{array}$ & UNDERGRADUATE DEGREE & SUBJECT(S) \\
\hline Arts and Humanities & Degree in History & Inglés científico para la historia \\
\hline \multirow{7}{*}{$\begin{array}{l}\text { Engineering and } \\
\text { Architecture }\end{array}$} & $\begin{array}{c}\text { Degree in Computer Engineering } \\
\text { Degree in Data Engineering }\end{array}$ & $\begin{array}{c}\text { Habilidades profesionales para } \\
\text { ingenieros }\end{array}$ \\
\hline & Degree in Architecture & English for architects \\
\hline & Degree in Civil Engineering & Inglés técnico \\
\hline & $\begin{array}{l}\text { Degree in Industrial Design and } \\
\text { Product Development Engineering }\end{array}$ & $\begin{array}{l}\text { Inglés técnico } \\
\text { Inglés técnico para IDIDP }\end{array}$ \\
\hline & Degree in Mechanical Engineering & $\begin{array}{l}\text { Inglés técnico I } \\
\text { Inglés técnico II }\end{array}$ \\
\hline & $\begin{array}{c}\text { Degree in Industrial Chemical } \\
\text { Engineering }\end{array}$ & $\begin{array}{l}\text { Inglés técnico I } \\
\text { Inglés técnico II }\end{array}$ \\
\hline & $\begin{array}{l}\text { Degree in Telecommunications } \\
\text { Technologies Engineering }\end{array}$ & $\begin{array}{c}\text { Inglés } \\
\text { Competencias comunicativas en } \\
\text { inglés }\end{array}$ \\
\hline \multirow{2}{*}{ Health Sciences } & Degree in Nursing & Inglés \\
\hline & Degree in Physiotherapy & Inglés científico-técnico I \\
\hline \multirow{3}{*}{ Social Sciences } & $\begin{array}{c}\text { Degree in Tourism } \\
\text { Dual degree program: Business } \\
\text { Management and Administration \& } \\
\text { Tourism }\end{array}$ & $\begin{array}{l}\text { Inglés turístico I } \\
\text { Inglés turístico II } \\
\text { Inglés turístico III }\end{array}$ \\
\hline & Degree in Social Work & Inglés aplicado al trabajo social \\
\hline & $\begin{array}{c}\text { Degree in Geography and Land-use } \\
\text { Planning }\end{array}$ & $\begin{array}{l}\text { Inglés aplicado a la } \\
\text { comunicacióncientífica }\end{array}$ \\
\hline
\end{tabular}

\section{CLIL versus EMI: an examination of their differences}

At this point, the differences between EMI and CLIL methodologies should be noted. CLIL methodology is not part of this study, but it might be useful, as mentioned previously, to clarify some of the differences between the two methodologies since there is a tendency to mistakenly 
think that they are the same. The main difference is that "CLIL programmes explicitly promote both content and language learning, unlike EMI programmes that focus only on content. When EMI is implemented in higher education, it is assumed that attention to language is not required because students presumably possess adequate proficiency in English" (Querol-Julián \& Crawford Camiciottoli, 2019, p. 10).

Some scholars, such as Dearden (2014), have discussed the differences between CLIL and EMI. She notes the following differences:

Whereas CLIL is contextually situated (with its origins in the European ideal of plurilingual competence for EU citizens), EMI has no specific contextual origin.

Whereas CLIL does not mention which second, additional or foreign language (L2) academic subjects are to be studied in, EMI makes it quite clear that the language of education is English, with all the geopolitical and sociocultural implications that this may entail.

Whereas CLIL has a clear objective of furthering both content and language as declared in its title, EMI does not (necessarily) have that objective (Dearden, 2014, p. 4).

Carrió-Pastor (2021, p. 24) also analysed the methodological differences between CLIL and EMI. In general terms, whereas CLIL is a dual-focused educational approach in which the language is an instrument of instruction to teach a determined set of contents, in EMI methodology, "language acquisition is not a priority but a consequence of using English as the language of instruction" (Carrió-Pastor, 2021, p. 22). Table 2 provides a clear and concise summary of the most relevant differences and similarities between these two methodologies, as noted in CarrióPastor (2021, p. 24).

Table 2. Differences and similarities between CLIL and EMI. Source: Carrió-Pastor (2021, p. 24).

\begin{tabular}{|l|l|}
\hline \multicolumn{1}{|c|}{ CLIL } & \multicolumn{1}{c|}{ EMI } \\
\hline It considers content and language learning & $\begin{array}{l}\text { It considers only content learning; the language } \\
\text { proficiency of students is taken for granted }\end{array}$ \\
\hline $\begin{array}{l}\text { Students enrolled in CLIL subjects do not need to } \\
\text { be highly proficient in a foreign language }\end{array}$ & $\begin{array}{l}\text { Students enrolled in EMI subjects should be } \\
\text { highly proficient in English }\end{array}$ \\
\hline $\begin{array}{l}\text { Taught in primary school (reinforces language } \\
\text { acquisition and proficiency) }\end{array}$ & $\begin{array}{l}\text { Taught in bilingual secondary schools (for } \\
\text { students with high language proficiency) }\end{array}$ \\
\hline $\begin{array}{l}\text { Taught in secondary school (reinforces language } \\
\text { acquisition and proficiency) }\end{array}$ & $\begin{array}{l}\text { Taught in universities (for students with high } \\
\text { language proficiency or international students) }\end{array}$ \\
\hline
\end{tabular}




\begin{tabular}{|l|l|}
\hline $\begin{array}{l}\text { Content teachers trained in foreign language } \\
\text { methodology teach the subjects }\end{array}$ & $\begin{array}{l}\text { Content teachers or language teachers trained in } \\
\text { content teach the subjects }\end{array}$ \\
\hline $\begin{array}{l}\text { Content teachers and language teachers should } \\
\text { work together }\end{array}$ & Materials are designed by content teachers \\
\hline $\begin{array}{l}\text { Materials should be designed by both content } \\
\text { and language teachers }\end{array}$ & $\begin{array}{l}\text { Methodology designed by content teachers as } \\
\text { language is not considered a priority }\end{array}$ \\
\hline $\begin{array}{l}\text { Methodology should be designed by both } \\
\text { content and language teachers }\end{array}$ & $\begin{array}{l}\text { Methodology follows communicative approach } \\
\text { and content-based approach }\end{array}$ \\
\hline $\begin{array}{l}\text { Methodology follows the communicative } \\
\text { approach and content-based approach }\end{array}$ & Assessment of only content acquisition \\
\hline Assessment of content and language acquisition & \multicolumn{2}{|l}{} \\
\hline
\end{tabular}

\section{II.2. EMI methodology and its implementation at the ULPGC}

This paper uses the definition of EMI offered by Dearden (2014, p. 4), which states that EMI consists of "The use of the English language to teach academic subjects in countries or jurisdictions where the first language (L1) of the majority of the population is not English". As the author points out, studies dealing with EMI are pertinent because "We do not know enough with regard to the consequences of using English rather than the first language (L1) on teaching, learning, assessing, and teacher professional development" (Dearden, 2014, p. 4). In institutions such as the ULPGC, the integration of these EMI subjects in the curricula of a variety of degrees is still very recent, and even today, the teaching advisory committees of many degrees are still considering the desirability of including subjects taught using EMI methodology. For this reason, this paper does not focus on the analysis of the consequences of doing this, which will need to be conducted in a few years' time, rather it focuses on the conditions that must be met for the possible integration of these subjects in the ULPGC degrees in which they do not yet exist, specifically, the degree in tourism.

Subjects taught using EMI have been incorporated into numerous undergraduate degrees throughout Spain. However, as previously mentioned, this methodology is much less widespread among the degrees at the ULPGC than is ESP. One of the main reasons for this is that, as numerous specialists state, the level required for students to be able to follow the teaching sessions of a subject entirely in English should be at least B2 or C1 of the CEFRL; however, according to Mendoza Domínguez (2017), "a significant amount of our undergraduate students start their different degrees having an intermediate level of English (B1). This level would be insufficient to start an EMI program". This applies not only to the ULPGC but probably to most Spanish universities as well. Furthermore, the institution should have teaching staff with a good command of the English language ( $\mathrm{C} 1$ or $\mathrm{C} 2$ level) as well as didactic training to ensure 
that students who are non-native English speakers are able to understand the content taught and that the lecturer is efficient in communicating this content. For this reason, the aim of this article is to analyse the conditions that should be in place for the future implementation of subjects taught using EMI methodology.

In the ULPGC, the number of subjects currently taught following EMI methodology is quite small and the degrees in which complete subjects are taught in English are even less numerous, but there are some, for instance, in the last year of the degree in economics. In other degrees, such as the degree in veterinary medicine, some credits are taught in English; for example, of the six European Credits (ECTS) assigned for a subject, five are taught in Spanish and one in English. However, what all the degrees in which there are credits taught through EMI at the ULPGC have in common is that they do not have ESP subjects for students to acquire the necessary level of competence to enable them to successfully follow and participate in specific and specialised content sessions taught in English.

One aspect to be taken into account when implementing subjects of this type is teacher training. As Carrió-Pastor (2021, p. 24) points out, these subjects are usually taught by "content teachers or language teachers trained in content". What it is necessary to be aware of is that it is not just a matter of explaining content and assuming that the students understand it; it is necessary to apply a methodology in which there is a higher level of interaction in order to be able to effectively monitor the students' level of understanding. It is also advisable to provide a high level of language feedback to the students enrolled in the subjects to help them become aware of areas they need to work on.

As shown in Table 2, EMI subjects do not include the teaching of general English language content but presuppose a high level of language proficiency on the part of the students, which should enable them to follow the teaching sessions and understand the content. This is important when considering the implementation of EMI subjects, as students who want to enrol in the subjects must be made aware of the minimum level of English proficiency they must have in order to be able to take the subjects. However, a review of syllabi for some of the current EMI subjects at the ULPGC shows that there is no reference to this in the prerequisites.

In addition to these issues, with the implementation of this methodology in Spanish higher education institutions, the belief has arisen that ESP or general English subjects can be removed from degrees and replaced by EMI, as many faculties believe that students will acquire a good level of English simply through EMI subjects. However, as Mendoza Domínguez (2017) points out, "There is no proof yet of the fact that students improve their English skills by studying the 
content of their degrees' subjects through English. We all should ensure priority of learning over innovation".

This issue is particularly relevant in degrees such as tourism, since a very high percentage of graduates of this degree will frequently carry out work tasks that require the use of foreign languages and which, in general, will not be directly related to the specialised subjects of their degrees; therefore, in many cases the concepts and terminology acquired during EMI sessions will not be put into practice so frequently when carrying out some of the functions these sessions feature. In fact, as indicated on the website of the Faculty of Economics, Business and Tourism of the ULPGC, the following are among the professional opportunities for the degree:

holding positions of management and responsibility in the different areas of tourism: accommodation, catering, intermediation, transport and logistics, planning and management of tourist destinations, products and activities, alluding to what is usually called complementary offer and the different types of tourism. In addition, the Graduate in Tourism also qualifies students to occupy other positions of responsibility in sectors directly or indirectly related to tourism activity.

Looking at the possible employment opportunities for the graduates of this undergraduate program, it becomes clear that the need for general English subjects to form part of the syllabus of the degree is of vital importance as these courses are necessary to complete the tasks related to the positions mentioned above and are even more relevant in a socio-economic environment such as that of the Canary Islands, in which the ULPGC is integrated, whose tourism sector offers services to millions of foreign tourists every year.

\section{PROPOSAL OF CONDITIONS FOR THE SUCCESSFUL IMPLEMENTATION OF EMI SUBJECTS IN THE DEGREE IN TOURISM AT THE ULPGC}

\section{IV.1. Language proficiency level as a prerequisite for EMI subjects}

Based on the aforementioned theoretical issues related to EMI methodology as well as the analysis of the current application of EMI in diverse universities, some recommendations can be made regarding the requirements for the implementation of EMI in any degree programme, and in particular, in the ULPGC's bachelor's degree in tourism. First of all, it is essential that a series of conditions are met in various dimensions of the teaching and learning process so that students can get the most out of EMI subjects. The most obvious is that, as a prerequisite for taking the subjects, students must have a good command of the English language; at least B2, or even C1, 
of the CEFRL is recommended, depending on the degree of specialisation of the subject. Furthermore, this requirement must be indicated among the prerequisites in the syllabus for the subjects.

In order to meet this requirement, the university has two options. One is to request the minimum level of English language proficiency on entry to the degree. However, this could be seen as an inequitable measure, since not all students have the means to pay for this kind of preparation and a public university should not discriminate in this respect. The second option is to have some courses of general English so that, once the students have acquired the required linguistic competences in both comprehension and expression, they can subsequently take subjects taught in English and follow the teaching sessions correctly.

As indicated above, some ULPGC degrees include EMI subjects but do not include any instrumental English subjects prior to the EMI subjects. Likewise, the syllabuses of these subjects do not state that students are required to have a specific level of English, so it can be assumed that the level required is the entrance level. It should be remembered that the level of access to university in Spain is generally between $A 2$ and $B 1$ of the CEFR although this is obviously a general requirement because it depends on the academic background of the students prior to entering university. In addition, by the time students take EMI subjects in advanced degree courses (third, fourth years or even higher in the case of degrees lasting more than 4 years), they have spent 2-3 years without having taken any English language subjects. It is assumed that they will be able to follow the foreign language sessions without difficulty without having been offered any subjects preparing them for those subjects in which specialised content is taught.

Introducing EMI subjects without taking into account the students' level of language usually results in the sacrifice of part of the content because the pace of work cannot be as it should due to the lack of language skills necessary to follow the sessions, and the participation in the sessions is reduced. This issue is not new and has been discussed in the context of other methodologies, such as CLIL. For instance, during the last decade the rector at the Politecnico di Milano University, Giovanni Azzone, claimed "[we] strongly believe our classes should be international classes - and the only way to have international classes is to use the English language" (Coughlan, 2012). However, there was a critical movement against the implementation of EMI at the institution, as had already happened at other higher education institutions. Professor Matricciani of the same University argued that "Speaking Italian to our countrymen is like watching a movie in colour, high definition, very clear pictures. On the contrary, speaking English to them, even with our best effort, is, on the average, like watching a movie in black and white, with very poor definition, with blurred pictures" (Coughlan, 2012). 
What must be understood is that institutions should not put students in the position of having to seek additional training outside the institution itself in order to be able to follow the sessions of the degree in which they are enrolled, as not everyone has that option due to, for example, economic, family or time constraints. A public university should guarantee equal opportunity. However, in the case of these mentioned degrees, ULPGC does not offer (a) the option of taking the same compulsory subjects in the official language of the country, in this case, Spanish, or (b) the option of taking ESP subjects within the degree itself to provide students with the necessary tools to follow the EMI subjects. In other countries, such as Turkey, some higher education institutions offering degrees with EMI subjects include a preparatory year so that students can acquire the necessary language level to be able to follow the sessions in the degree itself. However, this would mean adding an extra year to the duration of university studies.

Certainly, incorporating EMI subjects within the curricula of degree programmes without taking into account the need for a minimum level of English proficiency has consequences; the main one being that students do not make the most of these subjects and that problems are frequently detected in the understanding of the content taught. The latter issue has been demonstrated in studies carried out in various countries, as reported by Querol-Julián and Crawford Camiciottoli (2019). In their work, the following studies, among others, are cited as examples demonstrating this issue: 
Table 3. Results obtained in studies on students' comprehension of EMI lectures. Source: Querol-Julián and Crawford Camiciottoli (2019).

\begin{tabular}{|c|c|c|c|}
\hline Study & Country & Students & Lecture Comprehension \\
\hline Hellekjær (2010) & Norway & $\begin{array}{l}346 \\
\text { undergraduates } \\
\text { and } 45 \text { graduates }\end{array}$ & $\begin{array}{l}\text { A large number had comprehension } \\
\text { problems }\end{array}$ \\
\hline $\begin{array}{l}\text { Belhiah and } \\
\text { Elhami (2015) }\end{array}$ & $\begin{array}{l}\text { United Arab } \\
\text { Emirates }\end{array}$ & $\begin{array}{l}500 \\
\text { undergraduates }\end{array}$ & $17 \%$ had comprehension problems \\
\hline $\begin{array}{l}\text { Macaro and } \\
\text { Akincioglu } \\
\text { (2018) }\end{array}$ & Turkey & $\begin{array}{l}472 \\
\text { undergraduates }\end{array}$ & $\begin{array}{l}\text { Students responded with a mean of } 3.71 \\
\text { (on a Likert scale from } 1 \text { [low] to } 5 \\
\text { [high]) to having comprehension } \\
\text { problems }\end{array}$ \\
\hline $\begin{array}{l}\text { Soruç and } \\
\text { Griffiths (2018) }\end{array}$ & Turkey & $\begin{array}{l}39 \\
\text { undergraduates }\end{array}$ & Most had comprehension problems \\
\hline $\begin{array}{l}\text { Wang et al. } \\
(2018)\end{array}$ & China & undergraduates & Most had comprehension problems \\
\hline
\end{tabular}

\section{IV.1.1. Teaching groups distribution and materials}

Dividing students into small groups for teaching ESP or EMI subjects allows for more individualised attention and facilitates interaction, enabling students to develop their oral expression. However, in a large number of institutions and degrees this practice is complicated and does not usually happen due to organisational and economic constraints. A review of syllabi of some of the subjects currently taught using EMI methodology at the ULPGC shows that some of them do not include activities that promote the development of the different language skills, and so in no case can it be concluded that by taking these subjects students acquire a specific level of language in all the dimensions of expression, interaction and comprehension. Even if it could be considered that students acquire a certain level of foreign language competence in terms of, for example, written comprehension skills, the level of development of the skills of expression in particular is not clear. A similar level of proficiency within a specific group of students can facilitate the development of the teaching sessions, so offering instrumental English language subjects early on in the degree could help in homogenising the language level of the group, thus assisting the subsequent teaching of the EMI subjects. 
Another issue to be taken into account when implementing an EMI subject is the design of materials and their potential to facilitate understanding. In Spanish universities, the lecture is still the predominant methodology. Yet, although it should not be considered a wrong tool, it is true that some aspects must be adapted:

[Lecturers] would need to know how to modify their input, assure comprehension via student-initiated interactional modifications and create an atmosphere where students operating in an L2 are not afraid to speak; all this whilst taking into account the many cultural differences present in the room and the potentially different language levels of individuals (Dearden, 2014, p. 23).

When teaching sessions through EMI, it is necessary to consider that students must be provided with various types of support to facilitate their understanding of the content. In other words, it should not simply be a session in which the teacher transmits the information orally, but other types of resources and support should be used to facilitate communication, such as, for example, the use of presentations. The reason for this is not only the fact that a foreign language is being used to transmit the information, but also the fact that since it is content that many of the students are hearing for the first time, their level of comprehension is likely to be lower than expected. Furthermore, intonation, articulation and the speed at which the information is conveyed must also be adapted to the learners' ability to follow.

As an additional resource, materials for self-study outside the classroom can be considered an effective tool to help learners experiencing difficulties keep up with the pace of the teaching sessions as well as broaden their knowledge. As far as language learning is concerned, some years ago, the ULPGC set up the Centro de Recursos para el Aprendizaje Autónomo de Lenguas, a platform where students can access resources to develop their language skills in a variety of languages, including English, in an autonomous manner.

\section{IV.1.2. Lecturers' training and complementarity of EMI subjects with ESP subjects within the degree in tourism}

In a study conducted by Dearden (2014) in 55 countries, to the question 'Are there enough qualified teachers in your country to teach through EMI?', the answer was a resounding ' $N o$ ', with 83 per cent of countries responding in this way (2014, p. 24), and 
Spain is no exception in this respect. The issue is that in Spain, there is a lack of teacher training at the methodological level with regard to EMI. This lack of training leads to terminological confusion, the erroneous design of materials and teaching sessions, resulting in the poor development of students' knowledge and the low number of the subjects taught using this methodology. It can be said that the vision of many of the teachers who teach subjects in university education using EMI methodology is overly simplistic and lacks a theoretical basis. They need to be aware that, among other things, "EMI involves changing from a teacher-led style to a more interactive dynamic" (Dearden, 2014, p. 23).

ULPGC's degree in tourism currently includes three ESP subjects. Ideally, EMI subjects in this degree would be included in the third and fourth years, once the students have completed the ESP subjects in which English language content is taught, which are instrumental for the development of the students' communicative competences. Moreover, in a degree containing both types of subjects, cooperation between the ESP and EMI teachers should be promoted.

In a degree programme such as the bachelor's degree in tourism, it is essential to have subjects that help students achieve a high level of linguistic proficiency. However, as indicated in the theoretical framework, there is no evidence that this level is achieved through EMI subjects, as, according to Airey (2012, p. 11), teachers of EMI subjects "perceived teaching duties are content specific and language free"; therefore, in general, teachers do not correct language use; the important thing is that students are able to convey the content and not how they express it. In addition, this would be very specific content relating to very specific specialised subjects, and, depending on the work students carry out at the end of their studies, it would be unlikely for them to need such specialised concepts to carry out their tasks in the majority of jobs.

However, the way of expressing oneself and the correct use of the language is fundamental to the effective performance of the jobs to which they can gain access once they have finished their studies, especially jobs in which they have to deal with the public. This is evident in almost all job offers to tourism graduates, which require the ability to speak one or more foreign languages at an intermediate-advanced level. Companies cannot afford to hire someone who has not mastered at least the current 
lingua franca and who is not capable of interacting in specific communicative situations - skills best developed through ESP sessions and by putting them into practice through the internships offered by the Faculty of Economics, Business and Tourism.

\section{CONCLUSIONS}

Having reviewed the literature and determined the current situation regarding ESP and EMI subjects at the ULPGC, it can be concluded that one of the conditions required to implement subjects taught with EMI in the degree in tourism is the need for students to have an upper intermediate or advanced level of English. To meet this language prerequisite while ensuring equal opportunities among the enrolled students, the most coherent and efficient way forward would be to maintain the three current ESP subjects that cover levels B1 and B2 of the CEFR and that are provided in the first two years of the degree. It would also be advisable to introduce a fourth ESP subject so that the language level of the students is as close as possible to C1 of the CEFR, thus facilitating the development of the possible EMI subjects that are to be introduced. The EMI subjects should be included in the third and fourth years of the degree, after the students have completed the ESP subjects. In addition, the teaching projects for EMI subjects should state the language level needed as a prerequisite for taking the subjects, as is already done with ESP subjects, as this could be useful as an orientation for students.

Another conclusion drawn is that the teaching groups formed for the delivery of these sessions should be small in order to provide a controlled learning environment in which students feel comfortable communicating in the foreign language. Moreover, a small number of students allows for a higher level of student interaction with the teacher as well as with their peers. This could also be applied to existing ESP subjects, as it has been noted that the progress of some groups is slower precisely because they have a larger number of students than other groups.

Finally, some requirements should be established for teachers of EMI subjects to ensure that, in addition to a language level that allows them to teach these subjects, they have training in EMI methodology so that they understand that it does not mean translating content from Spanish into English. They should be aware that teaching specialised content, about which the audience usually has no prior knowledge, in a language that is not the students' mother tongue is not the same as teaching said content in the students' mother tongue. Thus, the materials used, support for these materials, possible reinforcements, work dynamics, etc. should be adapted to complement the master classes that may be given. 
The implementation of the recommendations listed here will result in an improvement in student outcomes as well as in the coherent implementation of a methodology that can have a very positive impact both on students' university training and on their subsequent professional development. If implemented correctly, the combination of ESP and EMI subjects within the same degree will not only help the development of students' language skills but will most likely have a positive effect on their confidence and fluency in using the English language in different academic and professional environments.

\section{REFERENCES}

Airey, J. (2012). I don't teach language. The linguistic attitudes of physics lecturers in Sweden. AlLA Review, 25(25), 64-79.

Belhiah, H., \& Elhami, M. (2015). English as a medium of instruction in the Gulf: When students and teachers speak. Language Policy, 14(1), 3-23.

Breeze, R., \& Dafouz, E. (2017). Constructing complex cognitive discourse functions in higher education: An exploratory study of exam answers in Spanish- and Englishmedium instruction settings. System, 70, 81-91. https://doi.org/10.1016/j.system.2017.09.024

Belcher, D. (Ed.). (2009). English for Specific Purposes in theory and practice. Ann Arbor, MI: University of Michigan Press.

Carrió-Pastor, M. L. (Ed.). (2020). Internationalising learning in higher education: The challenges of English as a medium of instruction. London: Palgrave Macmillan. https://doi.org/10.1007/978-3-030-21587-3

Carrió-Pastor, M. L. (2021). CLIL vs EMI: Different Approaches or the Same Dog with a Different Collar?. In Teaching Language and Content in Multicultural and Multilingual Classrooms (pp. 13-30). Palgrave Macmillan, Cham. https://doi.org/10.1007/978-3-030-56615-9-2

Carrió-Pastor, M. L., \& Bellés Fortuño, B. (Eds.). (2021). Teaching language and content in multicultural and multilingual classrooms. https://doi.org/10.1007/978-3-03056615-9 
Centro de Recursos para el Aprendizaje Autónomo de Lenguas. Universidad de Las Palmas de Gran Canaria. https://craal.ulpgc.es/node

Coughlan, S. (2012). Italian university switches to English. BBC News. https://www.bbc.co.uk/news/business-17958520

Dafouz, E., \& Camacho-Miñano, M. M. (2016). Exploring the impact of English-medium instruction on university student academic achievement: The case of accounting. $\begin{array}{llll}\text { English for Specific } & \text { 5urposes, }\end{array}$ http://dx.doi.org/10.1016/j.esp.2016.06.001

Dafouz, E., \& Smit, U. (2020). Road-Mapping English medium education in the internationalised university. London: Palgrave Macmillan. https://doi.org/10.1007/978-3-030-23463-8

Dearden, J. (2014). English as a medium of instruction - a growing global phenomenon. British Council. Retrieved from https://ora.ox.ac.uk/objects/uuid:4f72cdf8-b2eb4d41-a785-4a283bf6caaa

Doiz, A., Lasagabaster, D., \& Sierra, J. (2013). Globalisation, internationalisation, multilingualism and linguistic strains in higher education. Studies in higher education, 38(9), 1407-1421. https://doi.org/10.1080/03075079.2011.642349

Fortanet-Gómez, I. (2020). The Dimensions of EMI in the International Classroom: Training Teachers for the Future University. In Teacher Training for EnglishMedium Instruction in Higher Education (pp. 1-20). IGI Global. https://doi.org/10.4018/978-1-7998-2318-6.ch001

Furtado-Guimarães, F., \& Kremer-Martins, M. (2020). Adopting English as a medium of instruction (EMI) in Brazil and Flanders (Belgium): a comparative study. Ilh ado Desterro, 73, 217-246. https://doi.org/10.5007/2175-8026.2020v73n1p217

Hellekjær, G. O. (2010). Language matters: Assessing lecture comprehension in Norwegian English-medium higher education. In C. Dalton-Puffer, T. Nikula, \& U. Smit (Eds.), Language use and language learning in CLIL classrooms (pp. 233-258). Amsterdam: John Benjamins.

Hyland, K. (2002). Specificity revisited: How far should we go now? English for Specific Purposes, 21, 385-395. 
Isık-Tas, E. E. and Kenny, N. (2020). Current Practices, Challenges, and Innovations in English for Specific Purposes Instruction and Research. In Nalan Kenny, Elvan Eda Işık-Taş, Huang Jian (eds.). English for Specific Purposes Instruction and Research: Current Practices, Challenges and Innovations, (1-8). Cham, Switzerland: Palgrave MacMillan. https://doi.org/10.1007/978-3-030-32914-3

Macaro, E. (2018). English medium instruction. Oxford University Press.

Macaro, E., \& Akincioglu, M. (2018). Turkish university students' perceptions about English medium instruction: Exploring year group, gender and university type as variables. Journal of Multilingual and Multicultural Development, 39(3), 256-270.

Macaro, E., Jiménez-Muñoz, A., \& Lasagabaster, D. (2019). The importance of certification of English medium instruction teachers in higher education in Spain. Porta Linguarum, 32, 103-118. http://hdl.handle.net/10481/58569

Mendoza Domínguez, N. (2017). English as a Medium of Instruction (EMI) Innovating with responsibility. https://www.nebrija.com/medios/nebrijaglobalcampus/2017/04/27/english-asa-medium-of-instruction-emi-innovating-with-responsibility/. Accessed 2nd June 2021.

Querol-Julián, M., \& Crawford Camiciottoli, B. (2019). The impact of online technologies and English Medium Instruction on university lectures in international learning contexts: A systematic review.

Smit, U., \& Dafouz, E. (2012). Integrating content and language in higher education: An introduction to English-medium policies, conceptual issues and research practices across Europe. Aila Review, 25(1), 1-12. https://doi.org/10.1075/aila.25.01smi

Soruç, A., \& Griffiths, C. (2018). English as a medium of instruction: Students' strategies. ELT Journal, 72(1), 38-48.

Swales, J.M. (1988). Episodes in ESP: A source and reference book on the development of English for science and technology, 2nd edition. New York: Prentice-Hall.

Tejada-Sanchez, I., \& Molina-Naar, M. (2020). English medium instruction and the internationalization of higher education in Latin America: A case study from a 
Colombian university. Latin American Journal of Content \& Language Integrated Learning, 13(2), 339-367. https://doi.org/10.5294/laclil.2020.13.2.8

Tsou, W., \& Kao, S. (2017). English as a medium of instruction in higher education. English Language Education. Singapore: Springer Nature. https://doi.otg/10.1007/978-981-10-4645-2

Wang, Y., Yu, S., \& Shao, Y. (2018). The experiences of Chinese mainland students with English-medium instruction in a Macau university. Educational Studies, 44(3), 357360.

Wilkinson, R. (2012). English-Medium Instruction at a Dutch University: Challenges and Pitfalls. In Doiz, Lasagabaster and Sierra (Eds.), English-Medium Instruction at Universities: Global Challenges. Bristol, Blue Ridge Summit: Multilingual Matters, pp. 3-24. https://doi.org/10.21832/9781847698162-005

Received: 8 September 2021

Accepted: 26 September 2021 